\title{
Factors Influencing Rust (Melampsora apocyni) Intensity on Cultivated and Wild Apocynum venetum in Altay Prefecture, China
}

\author{
P. Gao,1,2 Z. B. Nan,1,3,4 M. J. Christensen,1,4 M. J. Barbetti,5 T. Y. Duan,1,3,4,† Q. T. Liu, ${ }^{6}$ F. J. Meng, ${ }^{6}$ and J. F. Huang6 \\ ${ }^{1}$ State Key Laboratory of Grassland Agro-Ecosystems, Lanzhou University, Lanzhou 730020, P. R. China; ${ }^{2}$ College of Animal Science and \\ Veterinary Medicine, Shanxi Agricultural University, Taigu, Shanxi Province 030801, P. R. China; ${ }^{3}$ Key Laboratory of Grassland Livestock \\ Industry Innovation, Ministry of Agriculture, Lanzhou University; ${ }^{4}$ College of Pastoral Agricultural Science and Technology, Lanzhou \\ University; ${ }^{5}$ School of Agriculture and Environment and the UWA Institute of Agriculture, Faculty of Science, The University of Western \\ Australia, Crawley, WA 6009, Australia; and ${ }^{6}$ Altay Gaubau Tea Co., Ltd., Altay 836500, P. R. China.
}

Accepted for publication 9 October 2018.

\begin{abstract}
Rust (Melampsora apocyni) on Apocynum venetum is the major constraint to the commercial development of this medicinal herb. To determine the factors influencing rust intensity (maximum disease index $\left[\mathrm{DI}_{\max }\right]$ ), rust was investigated from 2011 to 2015 in both cultivated and wild A. venetum plants. Partial least squares path modeling (PLS-PM) was used to analyze the paths and extent of the factors related to pathogen, environment, and host that affect rust intensity. $\mathrm{DI}_{\max }$ exhibited considerable variations across years and study sites, with variations linked to various factors fostering disease development. PLS-PM explained 80.0 and $70.1 \%$ of variations in $\mathrm{DI}_{\max }$ in cultivated and wild plants, respectively. Precipitation was the key factor determining $\mathrm{DI}_{\max }$ in both cultivated and wild plants (path coefficient $[\mathrm{PC}]=0.313$ and 0.544 , respectively). In addition, the topsoil water content in cultivated plants and the total vegetation coverage in wild plants were also critical determinants of
\end{abstract}

ABSTRACT
$\mathrm{DI}_{\max }$ via their effects on the microclimatic factor (contribution coefficients $[C C]=0.681$ and 0.989 , respectively; $\mathrm{PC}=0.831$ and 0.231 , respectively). In both cultivated and wild plants, host factors were mainly dominated by $A$. venetum density $(\mathrm{CC}=0.989$ and 0.894 , respectively), and their effect on $\mathrm{DI}_{\max }$ via the microclimatic factor (PC $=0.841$ and 0.862 , respectively) exceeded that via the inoculum factor $(\mathrm{PC}=0.705$ and 0.130 , respectively). However, the indirect effects led to $\mathrm{DI}_{\max }$ variation, while the dilution effect on host $(\mathrm{CC}=0.154)$ from weed in wild plants led to the indirect effect size in wild plants of 0.200 , which was lower than -0.699 in cultivated plants.

Keywords: Apocynum venetum, cultivated crop, disease index, path modeling, wild plant
Apocynum venetum belongs to the genus Apocynum of the family Apocynaceae and is widely distributed throughout Europe and in west, central, and east Asia. It is a perennial herbaceous shrub with a height of 0.8 to $3 \mathrm{~m}$ (Gao et al. 2015). During winter, the aboveground parts of the plant die but regenerate in spring, with new stems arising from spreading rhizomes (Thevs et al. 2012). Leaves of $A$. venetum are used as a traditional Chinese medicine and have been promoted as a nutritional tea supplement that has become increasingly popular in both North American and East Asian health food markets (Song and Zhou 2015). China remains the largest producer of $A$. venetum for human use, using leaves obtained mainly from the harvesting of wild plants. However, because there remain only two wild populations of this plants species in Altay Prefecture (Gao et al. 2015), more than 2,000 ha of cultivated A. venetum fields have been established since 2009 in Altay Prefecture, China. This is the only commercial cultivation of $A$. venetum worldwide and achieves an annual estimated value of tea products of U.S. \$13.6 million.

Rust, caused by Melampsora apocyni, which belongs the genus Melampsora of the family Melampsoraceae, is the major disease affecting A. venetum in several Asian and European countries (Gao et al. 2017). It was first observed on wild A. venetum in Russia (Tranzschel 1891) and has subsequently been reported on wild or cultivated A. venetum in Turkmenistan (Saccardo 1895), Japan

†Corresponding author: T. Y. Duan; E-mail: zyjt_721@163.com; duanty@1zu.edu.cn

Funding: This research was financially supported by the Integrated Disease Control Techniques (grant number 201191135) of The Science and Technology Department of Xinjiang Uygur Autonomous Region, China.

The author(s) declare no conflict of interest.

(C) 2019 The American Phytopathological Society
(Hiratsuka 1937), Kazakhstan (Nevodovskii 1956), Bulgaria (Denchev 1995), and Turkey (Kirbağ 2004). In China, since M. apocyni was first reported on wild A. venetum in Hebei Province in 1951 (Tai 1979), its distribution has expanded to wild or cultivated A. venetum in three other provinces or autonomous regions of China, including Henan (Tai 1979), Shanxi (Hu and Qian 1985), and Xinjiang (Zhuang 1989). In Altay Prefecture of Xinjiang, rust symptoms were first observed in 2009 on the leaves of both wild and cultivated $A$. venetum. The disease severely damages leaves, making them unsuitable for tea production and resulting in large economic losses (Gao et al. 2017). This necessitated studies into the factors influencing the intensity of rust occurrence, including the interactions of the pathogen with its host and the environment as a precursor to developing effective control procedures (Zadoks and Schein 1979).

Pathogenicity and host resistance are important factors influencing plant disease development (McCracken et al. 2000). Previous studies on rust caused by the genus Melampsora confirmed that, specifically, the presence of urediniospores leads to repeated cycles of infection during the growing season (Guo et al. 2010; Widin and Schipper 1980). Gao et al. (2014) showed that there were no differences in pathogenicity of $M$. apocyni urediniospores from cultivated versus wild plants of $A$. venetum in Altay Prefecture across 2012 to 2015. Both Peng et al. (2008) and Gao et al. (2015) confirmed that wild $A$. venetum plants in Altay Prefecture had a genetic relationship and morphological characteristics similar to those of cultivated plants. This is likely because cultivated plants had been propagated from seed that were collected from wild plants. However, variations in the $A$. venetum density in both cultivated and wild plants, and in their numbers of urediniospores that are spread by the wind, results in variable host-pathogen encounter rates and, consequently, in varying rust intensity in both cultivated and wild plants (Cox et al. 2004). 
For the genus Melampsora, urediniospore germination requires near $100 \%$ relative humidity or the presence of free moisture on the leaf surface, and occurs across temperatures from 5 to $28^{\circ} \mathrm{C}$ (Toome et al. 2010; Vialle et al. 2011). Urediniospores typically germinate and form two germ tubes, usually within 6 to $8 \mathrm{~h}$. One of these germ tubes infects the host leaf via stomata, generally within $24 \mathrm{~h}$ (Guo et al. 2010). However, in Altay Prefecture, a relative air humidity of near $100 \%$ is rare from May to September because this region has a continental semiarid climate (Habiken and Zhao 2011). Despite this, a large volume of rainwater is intercepted by the canopy of plants and adheres to the surface of foliage as droplets or water films (Huber and Gillespie 1992). Weather conditions, particularly both precipitation and temperature, are likely the key determinants of A. venetum rust intensity in Altay Prefecture. The microclimate within canopies of plants is also an important factor influencing rust development (Waggoner 1965). Furthermore, heat and water exchange continuously occur through air within and outside plant canopies and from the soil surface by way of topsoil water evaporation and from air movement. In this way, the topsoil water content and canopy density or vegetation coverage directly affect the microclimate in agricultural systems (Norman 1982). Changes in microclimate may also differ at various heights above the ground. As such, these changes lead to differences in timing and intensity of disease occurrence on different parts of plant (Costes et al. 2013; Schmitz and Grant 2009). Recognition of the vertical spread and development characteristics of rust on $A$. venetum would greatly contribute to our understanding of the relationship between the rust development process and the environmental factors encountered by the crop.

Although three alternate hosts for $M$. apocyni have been found-A. sibiricum in Kazakhstan (Nevodovskii 1956) and Pocynum pictum and $P$. hendersonii in China (Gao et al. 2015; Xu et al. 2013) — no such alternate hosts of M. apocyni occur in Altay Prefecture (Gao et al. 2017). In Altay Prefecture, weeds in A. venetum fields cannot be removed by either mechanical or other methods because of the requirement that all plants (including weeds) of the local ecological environment should be preserved (Ping et al. 2014). However, the weeds that are present could increase the closure of plant canopies, thus increasing the risk of rust epidemics (van Bruggen and Finckh 2016). In contrast, the presence of weeds that are not susceptible to rust could decrease hostpathogen encounter rates, resulting in decreased disease intensity (Mitchell et al. 2002). Furthermore, weeds in cultivated fields and among wild populations of $A$. venetum may affect the frequency at which $M$. apocyni urediniospores encounter $A$. venetum or alter the microclimate, thus leading to changes in rust intensity. For these reasons, the role of weeds in influencing rust intensity in cultivated and wild $A$. venetum plants needs careful consideration.

The specific objectives of this research were to (i) characterize the variation in rust intensity of both cultivated and wild plants across years, plant vertical direction, and sample sites during a 5year period of rust occurrence; (ii) determine the path and extent of the factors related to pathogen, environment, and host that affect rust intensity using partial least squares path modeling (PLS-PM); and (iii) establish the critical determinants of rust intensity in both cultivated and wild plants.

\section{MATERIALS AND METHODS}

Locations. Research was conducted at two locations (approximately $5 \mathrm{~km}$ apart) near the Alakak Township in Altay Prefecture of the Xinjiang Uyghur Autonomous Region, China. One was close to Lake Honggou, and contained a wild population of $A$. venetum (Honggou, $47^{\circ} 39^{\prime} \mathrm{N}, 87^{\circ} 31^{\prime} \mathrm{E}$, altitude 483 to $485 \mathrm{~m}$, area $1.47 \mathrm{ha}$ ). The second was situated near Lake Alakak and was also a wild population of $A$. venetum (Alakak, $47^{\circ} 42^{\prime} \mathrm{N}, 87^{\circ} 33^{\prime} \mathrm{E}$, altitude 492 to $547 \mathrm{~m}$, area $5.23 \mathrm{ha}$ ). Nearby, two cultivated fields of $A$. venetum had been established in $2010\left(\mathrm{CV} 2010,47^{\circ} 44^{\prime} \mathrm{N}, 87^{\circ} 32^{\prime} \mathrm{E}\right.$, altitude $510 \mathrm{~m}$, area $133 \mathrm{ha})$ and $2011\left(\mathrm{CV} 2011,47^{\circ} 43^{\prime} \mathrm{N}, 87^{\circ} 32^{\prime} \mathrm{E}\right.$, altitude
482 to $516 \mathrm{~m}$, area $866 \mathrm{ha}$ ) using plants grown from seed collected from local wild $A$. venetum.

In wild plants, the emergence of $A$. venetum stems began during early June. The soil was saline-alkali pH 7.8 to 8.2. From 2011 to 2015 , no attempts were made to control rust affecting wild A. venetum. In cultivated plants, soil was a sandy loam with a $\mathrm{pH}$ of 7.2 to 7.5, and $A$. venetum rows were spaced 1 and $3 \mathrm{~m}$ apart in CV2010 and CV2011, respectively. All of these cultivated A. venetum plants were spaced $1 \mathrm{~m}$ apart within rows. Emergence of A. venetum stems began in the middle of April and A. venetum were irrigated via drip irrigation every 2 days in 2011 and on 6 or 8 days per year from 2012 to 2015. In 2011 to 2013, no disease control measures were applied to cultivated $A$. venetum, with the exception of the fungicide triadimefon sprayed onto leaves by the grower twice per month in June and August of 2014 and 2015 to control rust.

Experimental design and sampling methodology. In CV2010, CV2011, Honggou, and Alakak, four repeated sampling plots each were chosen (each 20 by $30 \mathrm{~m}^{2}$ ) that were separated from other plots by an interval of 20 to $25 \mathrm{~m}$, arranged at four different directions (east, west, north, and south), pegged, and used to monitor rust from 2011 to 2015. Within each repeated sampling plot, five quadrats $\left(5 \times 5 \mathrm{~m}^{2}\right)$ were pegged and the variables data in relation to topsoil water content, vegetation, and $A$. venetum plant in each quadrat were collected. Furthermore, the mean value of five quadrats of each plot was recorded as one repeated sampling value of each site. However, in 2014 and 2015 due, to the fungicide (triadimefon) spraying onto leaves to control rust in cultivated A. venetum, rust was not monitored and data for these variables were not collected. Overall, there were two cultivated plants $\times$ wild plants $=$ four treatments with 16 plots.

Weather data collection. Air temperatures $\left({ }^{\circ} \mathrm{C}\right)$ and precipitation (in millimeters) were recorded every $15 \mathrm{~min}$ from May to September of each year via an automatic meteorological observation station (EM50; Decagon Devices, Inc., Pullman, WA) located at CV2011. Daily average temperatures and daily accumulated precipitation were calculated from daily records.

Estimation of urediniospore concentration in the air. Using a microbiological air sampler (Surface Air System Super 100; pbi Company, Milan, Italy), the concentration of $M$. apocyni urediniospore in the air in both cultivated and wild plants was measured every 2 days during the growing seasons from 2012 to 2015. One sampler was placed at the middle of each plot of CV2010, CV2011, Honggou, and Alakak. The sampler intake was at a height of $0.5 \mathrm{~m}$, with air sampled daily from 9.00 A.M. local time until 9.00 A.M. the following day. For daily sampling, the samplers were set to suck air at 30-min intervals until a total of 48 liters of airflow had passed through a detachable head with holes and had been directed onto the Vaseline-covered surface of a 9-cm-diameter Petri dish that was tightly inset in the head. Urediniospores adhering to the Vaselinecovered surface were identified using light microscopy according to their particular morphological characteristics, and the numbers of urediniospores present were recorded. The daily urediniospore concentration was expressed as the number of spores per cubic meter of air. The accumulated urediniospore concentration (AUC), before the disease index (DI) reached maximum value, was calculated for each year as follows:

$$
\mathrm{AUC}=\sum_{i=1}^{\mathrm{N}}\left[\left(y_{i}+y_{i+1}\right) / 2\right]\left[t_{i+1}-t_{i}\right]
$$

where $y_{i}$ is the urediniospore concentration at the $i^{\text {th }}$ observation, $N$ is the number of observations, and $t_{i}$ is the duration (in days) of the $i^{\text {th }}$ observation.

Topsoil water, vegetation, and A. venetum plant characteristics. In early June, July, and August of each year, topsoil was sampled to a depth of $20 \mathrm{~cm}$ using a soil auger at the central position of a single bush at the middle of each quadrat. Soil samples were immediately sealed in an aluminum box. The fresh weight of the soil was measured in the laboratory, then oven dried at $105^{\circ} \mathrm{C}$ for $48 \mathrm{~h}$ to determine the 
dry weight. The soil water content was presented as a percentage of the dried soil weight. The upper limit of the soil water content per quadrat was determined according to the gravimetric method developed by Bletsos et al. (1999). The relative soil water content is presented as a percentage of the upper limit of soil water content.

During the same period, the number of $A$. venetum stems in each quadrat was counted, and the total vegetation coverage and species diversity in each quadrat was measured using the point intercept method developed by Goodall (1952). The total vegetation coverage was estimated by recording the total number of vertical survey pin contacts with foliage. The coverage of each species was estimated by recording the number of species touched by each pin. The coverage data were expressed as the percentage of ground covered by all species or each species. A steel tape was used to measure the vertical height (in centimeters) of plants in each quadrat. The Shannon-Wiener index of diversity $\left(H^{\prime}\right)$ for the community of each plot was computed with the following formula:

$$
H^{\prime}=-\sum\left(P_{i} \ln P_{i}\right)
$$

where $P_{i}=\left(h_{i} / H+c_{i} / C\right) / 2 ; H$ and $C$ are the cumulative height and cumulative coverage, respectively, of all species in the quadrat

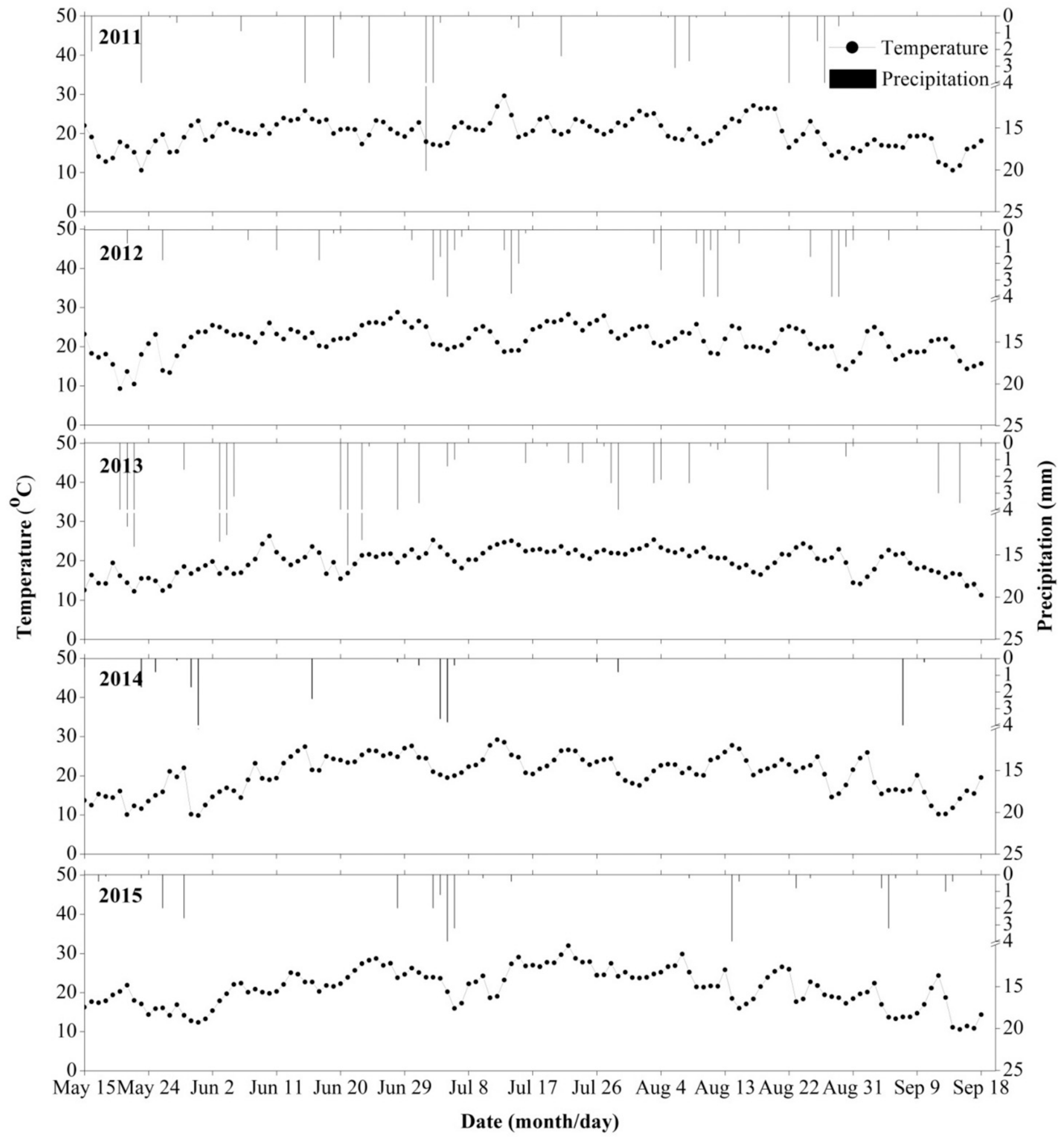

Fig. 1. Daily precipitation $(\mathrm{mm})$ and temperature $\left({ }^{\circ} \mathrm{C}\right)$ from mid-May to mid-September for 2011 through 2015 in Altay Prefecture of the Xinjiang Uygur Autonomous Region, China. 
population; and $h_{i}$ and $c_{i}$ are the mean values of height and degree of cover, respectively, belonging to the $i$ th species (Yang et al. 2011). Mean values of each variable in relation to topsoil water, vegetation, and $A$. venetum plants across the months from the date when rust was initially observed to the date DI reached maximum value were calculated for each year.

Monitoring of rust. Each year, the disease was evaluated at CV2010, CV2011, Honggou, and Alakak every 7 to 10 days from early May until the aboveground plant parts died (approximately at the end of August to early September). Ten A. venetum shrubs of roughly similar size and height were randomly chosen and marked in each plot; five stems of each shrub, including one at the center, were marked for rust assessment. Three leaves were randomly selected at each of the three sampling heights $-10 \mathrm{~cm}$ (lowest), 11 to $50 \mathrm{~cm}$ (middle), and $>50 \mathrm{~cm}$ (upper) above the ground of each marked stem-and rust severity was assessed on these. From each plot, in total, 450 leaves were assessed nondestructively for each assessment. Rust severity was estimated visually using an ordinal scale as the percentage of observed leaves covered by uredinia, as follows: $0=$ no signs of rust infection and $1=0.1$ to $5,2=5.1$ to 25 , $3=25.1$ to $50,4=50.1$ to 75 , and $5=75.1$ to $100 \%$ of leaf area covered with uredinia. The disease assessments ceased when aboveground plant parts died. DI was computed as a comprehensive index that included both disease severity and disease incidence (Harveson and Rush 2002; Ma et al. 2001), as follows:

$$
\mathrm{DI}=\left[100 \times \sum_{i}^{0}(i \times \mathrm{Ln})\right] /(5 \times \mathrm{LN})
$$

where $i$ is the disease severity scale $(i=0,1,2,3,4$, and 5) and LN and $\mathrm{Ln}$ are the total number of leaves and the number of leaves of each disease severity, respectively (Zhang et al. 2007). DI at each height was calculated and used to analyze the disease development on different plant parts. The mean DI of the three heights of each assessment was used to draw the temporal disease development curve. Following this, the maximum DI $\left(\mathrm{DI}_{\max }\right)$ in each disease development curve was excerpted as rust intensity.

Analysis of variables related to rust intensity. PLS-PM is a data analysis approach for studying observed variables that can be summarized by a latent variable (i.e., a variable that cannot be measured directly) and whether linear relationships exist between latent variables. The advantages of PLS-PM include the ability to

TABLE 1. Factorial analysis of variance for the relative soil water content, total vegetation coverage, diversity index, and Apocynum venetum density in cultivated and wild $A$. venetum plants $^{\mathrm{a}}$

\begin{tabular}{|c|c|c|c|c|}
\hline \multirow[b]{2}{*}{ Type } & \multirow[b]{2}{*}{ Variable } & \multicolumn{3}{|c|}{ Sources of variation } \\
\hline & & Month (M) & Year $(Y)$ & $\mathrm{M} \times \mathrm{Y}$ \\
\hline \multicolumn{5}{|l|}{ Cultivated } \\
\hline \multirow[t]{4}{*}{ CV2010 } & Relative soil water content & NS & $* *$ & NS \\
\hline & Total vegetation coverage & NS & $*$ & NS \\
\hline & Diversity index & NS & $*$ & NS \\
\hline & A. venetum density & NS & $*$ & NS \\
\hline \multirow[t]{4}{*}{ CV2011 } & Relative soil water content & NS & $* *$ & NS \\
\hline & Total vegetation coverage & NS & $*$ & NS \\
\hline & Diversity index & NS & $*$ & NS \\
\hline & A. venetum density & NS & $*$ & NS \\
\hline \multicolumn{5}{|l|}{ Wild } \\
\hline \multirow[t]{4}{*}{ Alakak } & Relative soil water content & $*$ & NS & NS \\
\hline & Total vegetation coverage & $*$ & $*$ & $*$ \\
\hline & Diversity index & NS & $*$ & NS \\
\hline & A. venetum density & $*$ & $* *$ & NS \\
\hline \multirow[t]{4}{*}{ Honggou } & Relative soil water content & $*$ & NS & NS \\
\hline & Total vegetation coverage & $*$ & $*$ & $*$ \\
\hline & Diversity index & NS & $*$ & NS \\
\hline & A. venetum density & $*$ & $*$ & NS \\
\hline
\end{tabular}

a NS $=$ not significant and $*$ and $* *$ indicate significant at the 0.05 and 0.01 probability levels, respectively. handle multicollinearity among independent variables, robustness in the face of data noise or missing data, and the fact that it allows the creation of independent latent variables directly on the basis of cross-products involving the response variables, leading to stronger predictions (Sanchez 2013). Therefore, because the data of this study showed multicollinearity, missing entries, and a small sample size $(n<100)$, PLS-PM was the most appropriate means to analyze interactions between rust density and its influencing factors.

First, we constructed the path model based on theoretical factors, knowledge, and logical assumptions about rust intensity (Lundquist 2007). We assumed that the weather and microclimatic within canopies of plants, host, and inoculum (amount of captured M. apocyni urediniospores) factors were the latent variables affecting rust intensity in both cultivated and wild plants. The formative relationships between these latent variables and the measurement variables (also known as manifest variables in PLS-PM) were defined as follows: the weather factor was dominated by the daily average air temperatures and cumulative precipitation, the microclimatic factor was dominated by the topsoil water content and the total vegetation coverage, the host factor was dominated by A. venetum density and species diversity, and the inoculum factor was dominated by the accumulated urediniospore concentration in the air. We assumed that (i) the weather, microclimatic, and inoculum factors directly affected rust intensity $\left(\mathrm{DI}_{\max }\right)$; (ii) the weather factor indirectly affected rust intensity via microclimatic or host factors; and (iii) the host factor had no direct effect on rust intensity but indirectly affected rust intensity via microclimatic or inoculum factors. The relationships between factors were connected by arrows and a path modeling diagram was constructed. Second, groups of data for analysis in cultivated $(N=24)$ and wild $(N=40)$ plants were created to a file of jobsat.csv and imported into the SmartPLS program (version 3.0; SmartPLS GmbH, Boenningstedt, Germany). Path modeling diagrams of both cultivated and wild plants were drawn in the Motivation Module of this program. Finally, the PLS-algorithm procedure of this program was applied to evaluate the validity of the models using the goodness-of-fit (GOF) statistic, which is a measure of their overall predictive power. If GOF > 0.7, the models were assessed to be valid, and then the procedure was continued to estimate the contribution coefficients (CC) of manifest variables to the latent variables, the standardized path coefficients (PC, representing the direction and strength of the linear relationships between latent variables), and the explained variability values $\left(R^{2}\right)$ associated with response variables (Kou et al. 2017). In addition, direct effects were obtained via PC for every connecting arrow between latent variables and indirect effects, calculated as the sum of multiplying these values (Sanchez 2013). The bootstrap-algorithm $(N=1,000)$ procedure in the SmartPLS program was applied to estimate the mean indirect effect size, its standard error, and the lower and upper critical value of $95 \%$ confidence interval $(95 \% \mathrm{CI})$. This method defined that the indirect effect had statistical significance if the $95 \%$ CI excludes zero value (Efron and Tibshirani 1993).

Data analysis. The DI at the three heights and the mean DI at the three heights $(X)$ in each repeated sampling plot were arcsine square-root transformed $(X+0.5)$, while the topsoil water content in each repeated sampling plot were Box-Cox transformed. The aim of these data transformations was to normalize data prior to analysis of variance (ANOVA). Two-way ANOVA was conducted to determine whether there were significant differences in the mean value of four repetitions of the relative soil water content, total vegetation coverage, diversity index, and A. venetum density in CV2010, CV2011, Alakak, and Honggou across both month and year. Using one-way ANOVA and $t$ tests, it was determined whether significant differences for the mean value of four repetitions of relative soil water content, total vegetation coverage, diversity index, and $A$. venetum density existed among the four study sites from 2011 to 2013 and between the two wild sites in 2014 and 2015. One-way ANOVA was also used to analyze the variation of $\mathrm{DI}_{\max }$ among all 
sites and years; DI among the three parts of plants for each assessment in each site in each year; and the mean values of relative soil water content, total vegetation coverage, diversity index, and $A$. venetum density across the months from the date when rust was initially observed to the date when DI reached maximum value among all sites and years. When a significant overall $F$ test was found via ANOVA, treatment means were compared using Fisher's least significant difference at $P=0.05$. Finally, the transformed disease indices and topsoil water contents were back transformed to the original scale and regressed as the observed values. Spearman's rank correlation tests were used to assess the magnitude of the relationships between $\mathrm{DI}_{\max }$ and the factors influencing rust intensity for both cultivated and wild A. venetum (Turechek 2004). These statistical analyses were conducted using the procedures of SPSS (version 19.0; IBM, Armonk, NY, U.S.A.).

\section{RESULTS}

Precipitation and temperature. In 2011 and 2013, 25 and 33 rainfall events, respectively, occurred from mid-May to
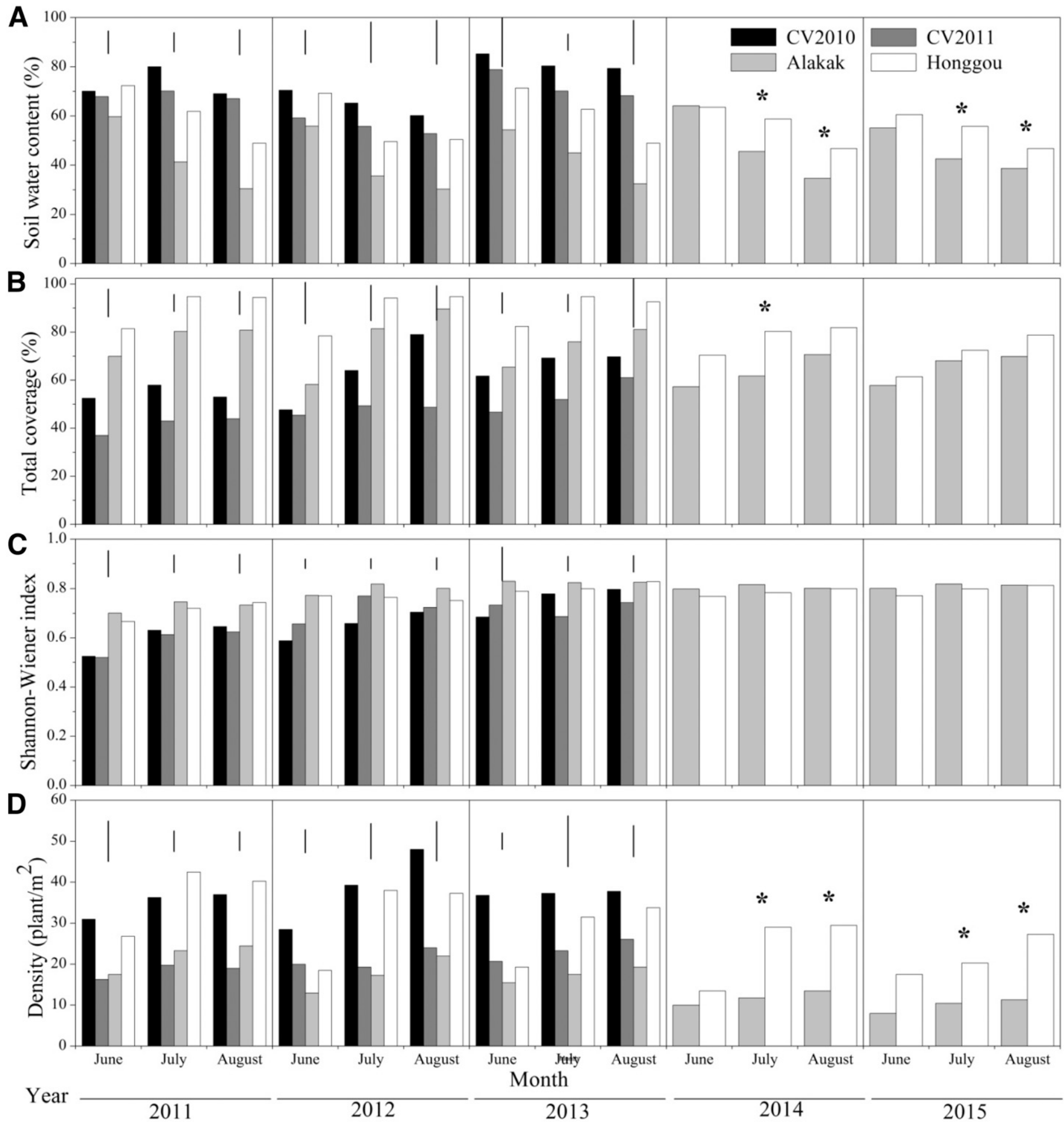

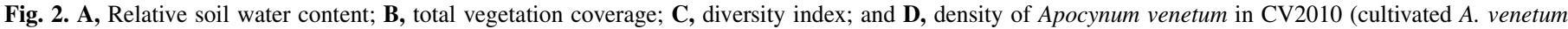

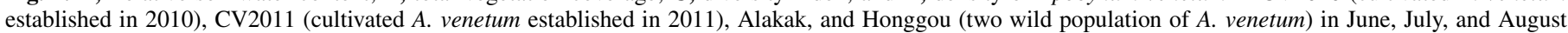

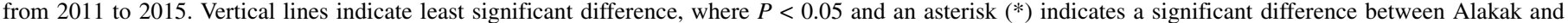
Honggou at $P=0.05$ using a $t$ test. 


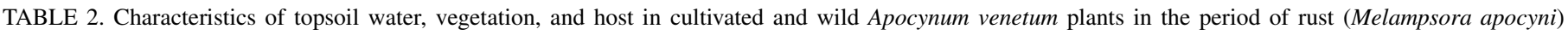
increase from 2011 to $2015^{\mathrm{a}}$

\begin{tabular}{|c|c|c|c|c|c|c|c|}
\hline \multirow{2}{*}{$\frac{\text { Year }}{2011}$} & \multicolumn{2}{|c|}{ Type } & \multirow{2}{*}{$\begin{array}{c}\begin{array}{c}\text { Relative soil water } \\
\text { content }(\%)\end{array} \\
77.5\end{array}$} & \multirow{2}{*}{$\begin{array}{c}\begin{array}{c}\text { Total vegetation } \\
\text { coverage }(\%)\end{array} \\
53\end{array}$} & \multirow{2}{*}{$\begin{array}{c}\begin{array}{c}\text { Species } \\
\text { diversity }\end{array} \\
0.6390\end{array}$} & \multirow{2}{*}{$\begin{array}{c}\begin{array}{c}\text { A. venetum density } \\
\left(\mathrm{stems} / \mathrm{m}^{2}\right)\end{array} \\
34\end{array}$} & \multirow{2}{*}{$\begin{array}{c}\begin{array}{c}\text { Accumulated urediniospore } \\
\text { concentration }\left(\text { spore } / \mathrm{m}^{3}\right)\end{array} \\
\ldots\end{array}$} \\
\hline & Cultivated & CV2010 & & & & & \\
\hline & & CV2011 & 69.2 & 40 & 0.5645 & 18 & $\ldots$ \\
\hline & Wild & Alakak & 43.7 & 75 & 0.7329 & 22 & $\ldots$ \\
\hline & & Honggou & 61.1 & 88 & 0.6802 & 37 & $\ldots$ \\
\hline \multirow[t]{4}{*}{2012} & Cultivated & CV2010 & 65.1 & 58 & 0.6506 & 39 & 93 \\
\hline & & CV2011 & 57.2 & 45 & 0.7390 & 21 & 76 \\
\hline & Wild & Alakak & 38.7 & 71 & 0.7978 & 19 & 60 \\
\hline & & Honggou & 56.7 & 81 & 0.7627 & 31 & 58 \\
\hline \multirow[t]{4}{*}{2013} & Cultivated & CV2010 & 81.1 & 61 & 0.7540 & 37 & 96 \\
\hline & & CV2011 & 74.1 & 46 & 0.7218 & 22 & 82 \\
\hline & Wild & Alakak & 42.7 & 70 & 0.8271 & 18 & 71 \\
\hline & & Honggou & 61.0 & 83 & 0.8010 & 25 & 61 \\
\hline \multirow[t]{2}{*}{2014} & Wild & Alakak & 45.2 & 64 & 0.8041 & 11 & 33 \\
\hline & & Honggou & 56.4 & 79 & 0.7843 & 24 & 31 \\
\hline \multirow[t]{3}{*}{2015} & Wild & Alakak & 40.4 & 60 & 0.8156 & 9 & 35 \\
\hline & & Honggou & 53.8 & 76 & 0.7947 & 23 & 5 \\
\hline & $\mathrm{LSD}^{\mathrm{b}}$ & $\ldots$ & 7.4 & 9.2 & 0.0295 & 4.1 & $\ldots$ \\
\hline
\end{tabular}

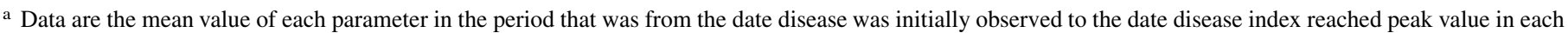
year.

b Least significant difference at $P<0.05$

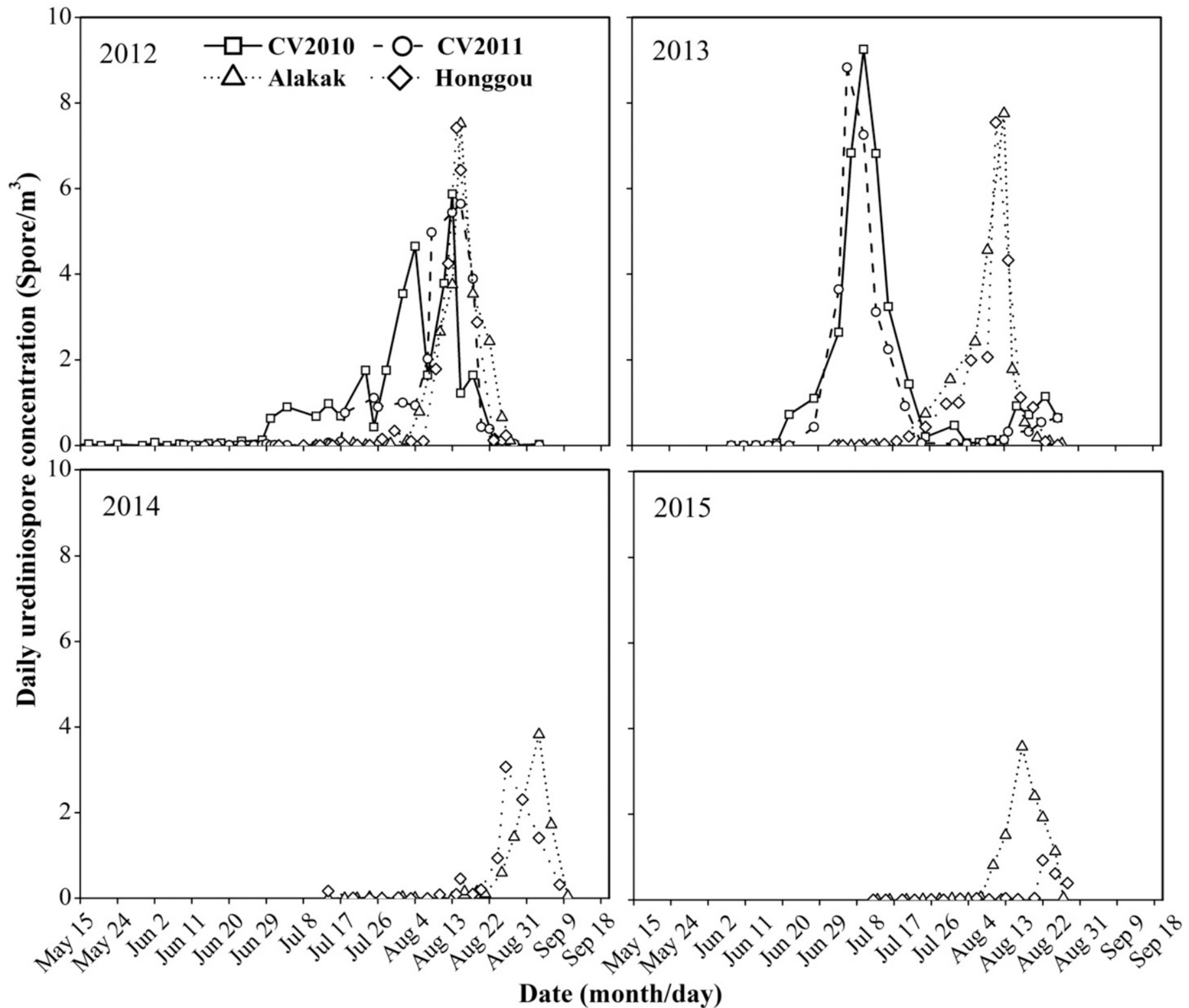

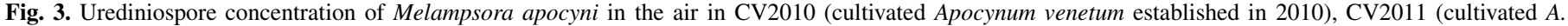
venetum established in 2011), Alakak, and Honggou (two wild population of A. venetum) in the growing seasons from 2012 to 2015. 
mid-September, of which 2 and 6 were heavy rain events (precipitation exceeding $8 \mathrm{~mm} /$ hour) that occurred in mid- to late June and late May to mid-June, respectively (Fig. 1). The total precipitation was 76.1 and $140.4 \mathrm{~mm}$, respectively. In 2014 and 2015, there were 13 and 22 rainfall events, respectively, that occurred from mid-May to mid-September. The total precipitation (33.6 and $33.7 \mathrm{~mm}$, respectively) was lower than that observed for 2011 and 2013 (Fig. 1). In 2012, precipitation in May and June was infrequent but both frequency and amount of rain increased in July and August (Fig. 1). In all, 29 rainfall events were observed with a
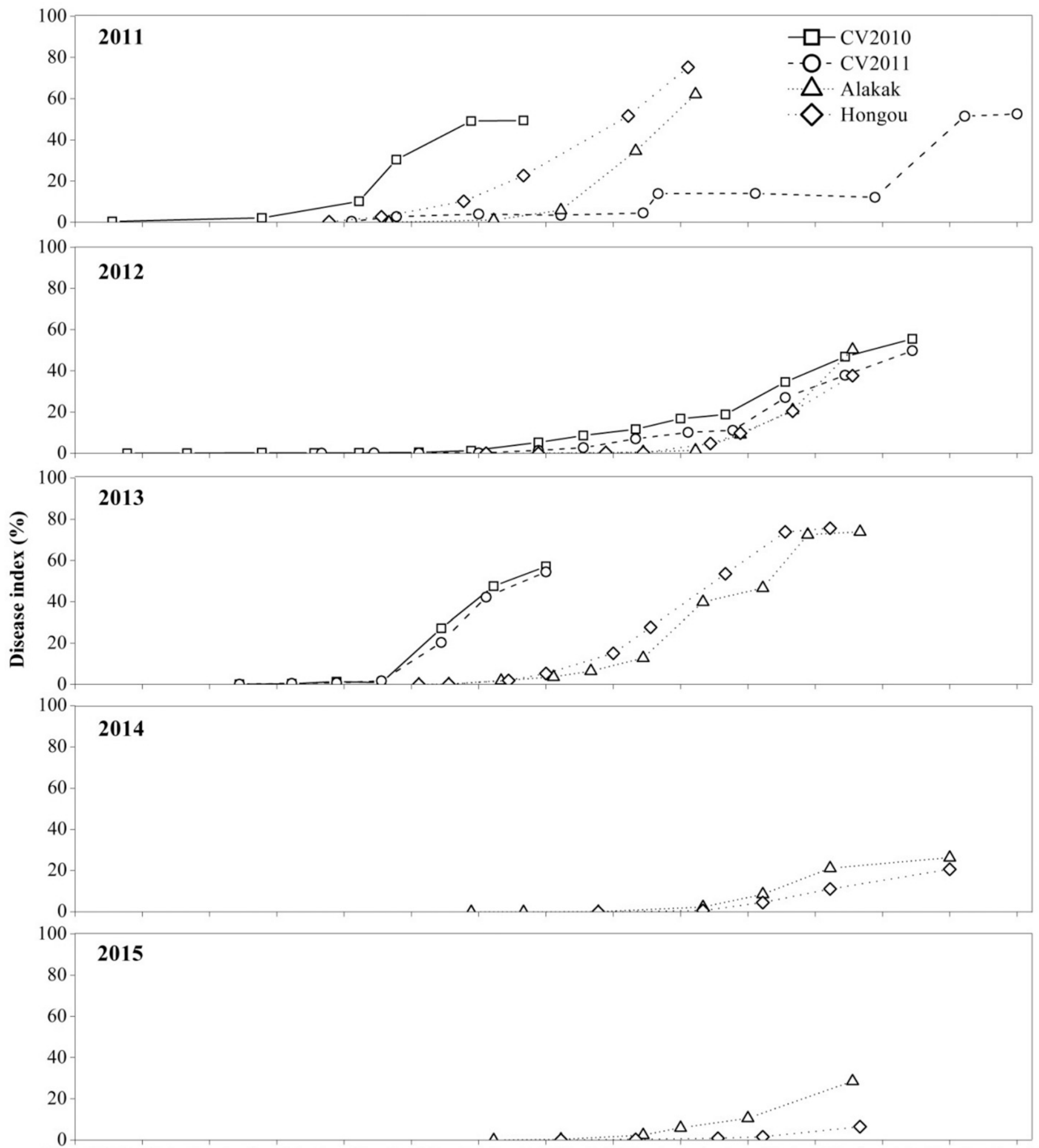

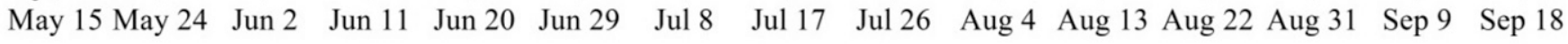

\section{Date (month/day)}

Fig. 4. Disease index (DI) of rust (Melampsora apocyni) over time in CV2010 (cultivated Apocynum venetum established in 2010), CV2011 (cultivated A. venetum established in 2011), Alakak, and Honggou (two wild population of A. venetum), from 2011 to 2015 . DI was calculated by the formula DI $=\left[100 \times \sum_{i}^{0}(i \times \mathrm{Ln})\right] /$ $(5 \times \mathrm{LN})$, where $i$ is the disease severity scale $(i=0,1,2,3,4$, and 5) and $\mathrm{LN}$ and $\mathrm{Ln}$ are the total number of leaves and the number of leaves of each disease severity, respectively. 


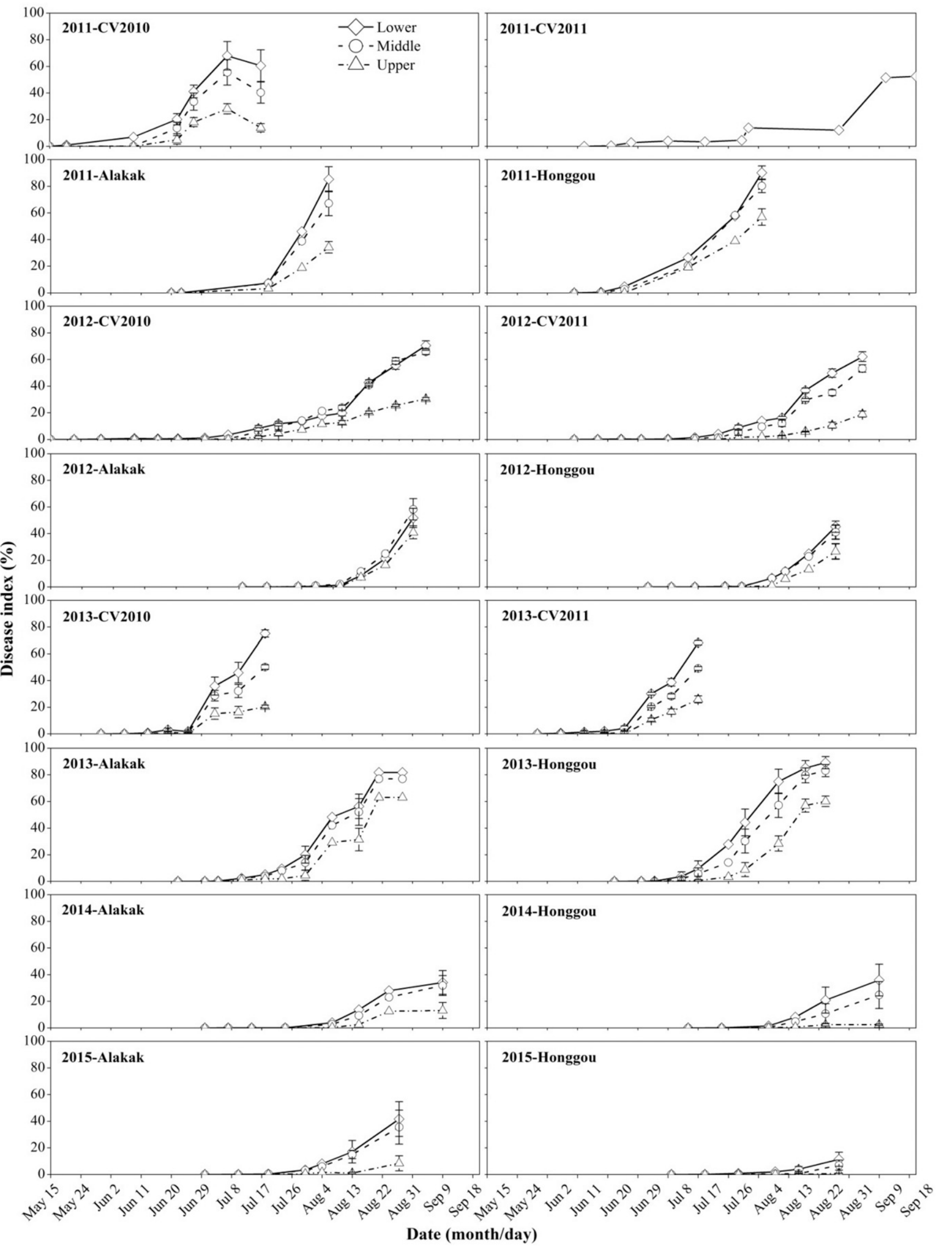

Fig. 5. Disease index (DI) of rust (Melampsora apocyni) on three parts of Apocynum venetum plants over time in CV2010 (cultivated Apocynum venetum established in 2010), CV2011 (cultivated A. venetum established in 2011), Alakak, and Honggou (two wild population of A. venetum) from 2011 to 2015 . DI was calculated by the formula DI $=\left[100 \times \sum_{i}^{0}(i \times \mathrm{Ln})\right] /(5 \times \mathrm{LN})$, where $i$ is the disease severity scale $(i=0,1,2,3,4$, and 5$)$ and $\mathrm{LN}$ and $\mathrm{Ln}$ are the total number of leaves and the number of leaves of each disease severity, respectively. Bars represent standard error of each mean. DI of lower leaves had a significant difference with middle or upper leaves of plant at $P=0.05$ using the least significant difference test. 
total precipitation of $63.4 \mathrm{~mm}$. The mean daily temperature from mid-May to mid-September during these 5 years ranged between 9.8 and $29.8^{\circ} \mathrm{C}$ (Fig. 1).

Characteristics of topsoil water, vegetation, and $A$. venetum plant. In cultivated plants, there was no significant $(P>0.05)$ change for the relative soil water content, total vegetation coverage, and diversity index across months (Table 1). However, the relative soil water content in wild plants decreased gradually across months (Fig. 2) and showed a significant difference $(P<$ $0.05)$ (Table 1). In contrast, the total vegetation coverage in wild plants increased significantly across months $(P<0.05)$ (Fig. 2; Table 1). No significant $(P>0.05)$ change was observed for the density of cultivated $A$. venetum across months, whereas the density of wild $A$. venetum increased significantly $(P<0.05)$ across months (Fig. 2; Table 1). With the exception of the relative soil water content in wild plants, these variables related to topsoil water, vegetation, and $A$. venetum in cultivated and wild plants showed significant $(P<0.05$ or 0.01$)$ differences across years (Table 1). For cultivated plants, the relative soil water content did not show a significant $(P>0.05)$ difference between CV2010 and CV2011 in each month, while the total vegetation coverage and the density of $A$. venetum of CV2010 in each month was greater than that of CV2011 $(P<0.05)$ (Fig. 2). The relative soil water content and the density of $A$. venetum of wild plants in Honggou was greater than that of Alakak in each month $(P<0.05)$ (Fig. 2$)$.

The mean relative soil water content in the periods of rust development of cultivated plants in 2011 and 2013 were 69.2 to $81.1 \%$ whereas, in 2012 , the values were only 57.2 to $65.1 \%$. Except for 2013, the mean relative soil water content of CV2011 was higher than that of CV2010 ( $P=0.034$ and 0.031$)$ (Table 2$)$. In wild plants, the mean relative soil water content during the period of rust development across years showed no significant differences $(P>$ 0.05 ) (Table 2), and the mean relative soil water content was lower than that of cultivated plants in 2011 and 2013. The mean values of total vegetation coverage in CV2010 were higher than that of CV2011 from 2011 to $2013(P=0.013,0.011$, and 0.004 , respectively). The mean values of the total vegetation coverage in Honggou were greater than that of Alakak, and the difference was significant $(P<0.05)$ in each year (Table 2$)$. Except for 2012, the mean diversity index of CV2010 was greater than that of CV2011 ( $P$ $<0.001$ and $P=0.028$ in 2011 and 2013, respectively). In 2011 and 2012, the mean diversity index of Alakak was greater than that of Honggou ( $P=0.013$ and 0.046 , respectively). In the remaining years, the mean diversity index between both fields had no significant difference $(P>0.05)$ (Table 2$)$. The mean density of $A$. venetum in CV2010 and Honggou were higher than that of CV2011 and Alakak in most years $(P<0.05)$ (Table 2$)$.

Urediniospore concentration in air. Urediniospores were not captured by samplers prior to disease onset in the plots of cultivated and wild plants. The urediniospore concentration increased gradually along with DI (Fig. 3). The maximum and accumulated urediniospore concentrations in cultivated plants in 2012 were less than those of 2013 (Fig. 2; Table 2). The maximum and accumulated values in wild plants in 2012 and 2013 were higher than those of 2014 and 2015 (Fig. 3; Table 2).

Assessment of rust development. Rust in cultivated plants usually first occurred from late May to early June. In contrast, wild plants did not exhibit rust symptoms until early June or July (Fig. 4). The DI of cultivated and wild plants gradually increased with time until it reached maximum values (Fig. 4). In cultivated plants, DI $I_{\max }$ in 2012 remained stable until the plants died naturally (early September), whereas $\mathrm{DI}_{\max }$ in 2011 and 2013 appeared earlier (early July) than in 2012. In wild plants, DI max $_{\text {from }} 2012$ to 2015 remained until the plants died naturally (from the end of August to early September), whereas DI max $_{\text {in }} 2011$ appeared earlier than in the other years (Fig. 4).

In cultivated plants, $\mathrm{DI}_{\text {max }}$ ranged from 49.4 to $57.1 \%$ from 2011 to 2013 , and $\mathrm{DI}_{\max }$ in wild plants ranged from 6.4 to $75.6 \%$ across
2011 to 2015, respectively (Fig. 4). DI ${ }_{\max }$ in cultivated plants in 2011 and 2013 was greater than in $2012(P<0.05)$, and DI $\mathrm{I}_{\max }$ values in wild plants in 2011,2012, and 2013 were greater than the values for other 2 years $(P<0.05)$ (Fig. 4). In cultivated plants, in 2011, $\mathrm{DI}_{\max }$ of CV2010 was lower than that of CV2011 $(P=0.039)$ whereas, in 2012 and 2013, DI max $_{\text {ax }}$ of 2010 was greater than that of CV2011 $(P=0.011$ and 0.031$)$. In wild plants, in 2011, $\mathrm{DI}_{\max }$ of Honggou was greater than that of the Alakak $(P=0.014)$, whereas the values of Honggou were lower than those of Alakak in 2012, 2014, and $2015(P=0.012, P=0.047$, and $P<0.001$, respectively $)$ (Fig. 4).

DI at different parts of plant. In cultivated plants, the observed dates of rust on the middle leaves were 6 to 7 days and 13 to 29 days later than for the lowest leaves for CV2010 and CV2011, respectively, while rust occurred on the uppermost leaves 7 to 39 days and 7 to 46 days later, respectively, compared with the lowest leaves (Fig. 5). In wild plants, the delayed onset of infection was 5 to 9 days and 7 to 17 days for Honggou and Alakak, respectively, on the middle leaves, while the observed delay was 1 to 14 days and 5 to 28 days, respectively, on the upper leaves (Fig. 5).

In cultivated plants, DI of the middle or upper leaves was less than that of the lowest leaves in the entire disease assessment process. DI of the middle and upper leaves were 39.4 to $53.4 \%$ and 52.3 to $72.9 \%$ lower, respectively, than those of the lowest leaves $(P<0.05)$ (Fig. 5). However, for wild plants, despite DI of the upper leaves being 31.2 to $94.7 \%$ less than those of the lowest leaves, the difference had statistical significance only in the later stage of this disease $(P<0.05)$ (Fig. 5).

Relationships between $\mathrm{DI}_{\max }$ and its influencing factors. $\mathrm{DI}_{\max }$ of cultivated plants was significantly positively correlated with the accumulated precipitation $\left(r^{2}=0.461, P=0.024\right)$, topsoil water content $\left(r^{2}=0.891, P=0.003\right)$, total vegetation coverage $\left(r^{2}=\right.$ $0.558, P=0.008)$, A. venetum density $\left(r^{2}=0.549, P=0.009\right)$, and accumulated urediniospore concentration $\left(r^{2}=0.716, P=0.004\right)$ (Table 3 ). DI $\mathrm{max}_{\max }$ of wild plants was also significantly positively correlated with the accumulated precipitation $\left(r^{2}=0.805, P=\right.$ $0.003)$, total vegetation coverage $\left(r^{2}=0.445, P=0.004\right)$, A. venetum density $\left(r^{2}=0.353, P=0.026\right)$, and accumulated urediniospore concentration $\left(r^{2}=0.749, P=0.004\right)$ but not for the topsoil water content. In addition, the latter showed a significant negative correlation with the species diversity index $\left(r^{2}=-0.367, P=0.020\right)$ (Table 3).

In wild plants, the accumulated precipitation showed a significant positive correlation with the total vegetation coverage $\left(r^{2}=0.401\right.$, $P=0.010)$ and $A$. venetum density $\left(r^{2}=0.457, P=0.009\right)$ (Table 3$)$; however, this was not the case in cultivated plants (Table 3 ). Whether in cultivated or wild plants, the accumulated precipitation did not show a significant $(P>0.05)$ positive correlation with the topsoil water content (Table 3 ). However, in both cultivated and wild plants, $A$. venetum density showed a significant positive correlation with the total vegetation coverage $\left(r^{2}=0.829, P=0.002\right.$ and $r^{2}=0.878, P=0.001$, respectively). The accumulated urediniospore concentration showed a significant negative correlation with the daily average temperature $\left(r^{2}=-0.632, P=0.007\right.$ and $r^{2}=-0.308, P=0.027$ ) (Table 3 ) in both cultivated and wild plants, respectively.

Analysis of the variations in $\mathbf{D I} \mathbf{I}_{\text {max }}$. In cultivated and wild plants, the GOF of PLS-PM were 0.72 and 0.71 , respectively, and the models explained 80.0 and $70.1 \%$ of the variations in $\mathrm{DI}_{\max }$, respectively (Fig. 6A and $\mathrm{B}$ ).

The CC of cumulative precipitation $(\mathrm{CC}=0.990$ and 0.969$)$ for the weather factor in both cultivated and wild plants, respectively, were greater than that of daily average temperatures $(\mathrm{CC}=0.038$ and -0.085 , respectively) (Fig. 6A and B). The topsoil water content in cultivated plants and the total vegetation coverage in wild plants had greater contribution ( $\mathrm{CC}=0.681$ and 0.989 , respectively) to the microclimatic factor compared with other dominated manifest variables (Fig. 6A and B). In both cultivated and wild plants, the 
contribution of the A. venetum density $(\mathrm{CC}=0.989$ and 0.894, respectively) to the host factor exceeded that of the species diversity $(\mathrm{CC}=0.072$ and -0.154$)$ (Fig. 6A and B). Microclimatic and weather factors in cultivated and wild plants, respectively, had a greater effect $(\mathrm{PC}=0.831$ and $\mathrm{PC}=0.544$, respectively, both $P<$ 0.001 ) on $\mathrm{DI}_{\max }$ than the other three factors (Fig. 6A and B). In cultivated plants, the weather factor had a significant $(\mathrm{PC}=0.313$, $P<0.05$ ) direct effect on $\mathrm{DI}_{\max }$ (Fig. 6A). However, in wild plants, the weather significantly $(\mathrm{PC}=0.862, P<0.001)$ affected the microclimate via the host factor $(\mathrm{PC}=0.579, P<0.001)$ (Fig. 6B), and this indirect process ultimately resulted in a variation of $\mathrm{DI}_{\max }$ (mean effect size $=0.119,95 \% \mathrm{CI}>0)($ Table 4). Despite the host factor remaining unaffected by the weather in cultivated plants (Fig. $6 \mathrm{~A}$ ), it had a significant (mean effect size $=0.699,95 \% \mathrm{CI}>0$ ) influence on $\mathrm{DI}_{\max }$ via microclimatic factor (Table 4). Furthermore, the host factor also significantly and positively $(\mathrm{PC}=0.705, P<$ $0.001)$ affected inoculum, and the effect was greater than that of wild plants $(\mathrm{PC}=0.130)$ (Fig. 6A and $\mathrm{B})$. However, the direct effect of inoculum on $\mathrm{DI}_{\max }$ had no statistical significance $(P>0.05)$ whether in cultivated or wild plants (Fig. 6A and B).

\section{DISCUSSION}

In both cultivated and wild $A$. venetum plants, there was considerable year-to-year heterogeneity in rust intensity $\left(\mathrm{DI}_{\max }\right)$ but there was no evidence of a significant correlation between rust intensity and daily average temperature. Moreover, temperature had a very small contribution to the overall weather conditions fostering rust intensity. This may initially be considered surprising given that others (Chandrashekar and Heather 1981; Widin and Schipper 1980) have reported that various components of the Melampsora pathogen life cycle (e.g., uredinia density and spore production on leaves) are dependent on temperature. However, during the period of rust development, the temperature in Altay Prefecture was 10.6 to $28.8^{\circ} \mathrm{C}$ over the 5-year period, which was favorable for the germination of Melampsora urediniospores and the resulting infection of leaves (Guo et al. 2010; Li et al. 2013). Thus, temperature may not vary sufficiently from year to year within this location to achieve a detectable level of association with rust intensity. In fact, in the absence of wetness (e.g., rain) or high atmospheric moisture levels (e.g., high relative humidity), temperature alone may be relatively unimportant for plant disease (Kriss et al. 2010). In the current study, the temperature in the rainy weather was 10.6 to $20.3^{\circ} \mathrm{C}$, which was still within the optimum range for rust development. Overall, temperature was not a limiting factor for rust development in both cultivated and wild $A$. venetum in Altay Prefecture, China.

In contrast to temperature, the current study highlighted a strong influence of precipitation on rust development, with differences in precipitation frequency and cumulative amounts responsible for the year-to-year variations in rust intensity. For example, in 2011, 2012, and 2013, DI began to increase continuously after heavy rain or frequent rain events, and the $\mathrm{DI}_{\max }$ in these years greatly exceeded that in the poor rainfall years of 2014 and 2015. This was not surprising, because precipitation is a known driver of disease occurrence and development not only with regard to rust caused by the genus Melampsora (Covarelli et al. 2013; Lawrence et al. 2007; Widin and Schipper 1980) but also for rust on other crops such as soybean (Glycine max) rust (Phakopsora pachyrhizi)(Schmitz and Grant 2009) and wheat stripe rust (Puccinia glumarum) (Eversmeyer and Kramer 2000; Zeng and Luo 2006).

In cultivated plants, the topsoil was always kept wet due to the application of drip irrigation, thus concealing any significant relationship between the soil water content and precipitation. Importantly, this continuously wet topsoil led to an increased rust intensity as a consequence of its effect on the microclimatic factor, and the extent of this influence exceeded the influence of weather. In addition, variations in timing and intensity of rust occurrence among three parts of cultivated plants were also found in the entire rust development progress. In particular, rust on the lowest leaves was also most influenced by the topsoil water content (e.g., rust first developed on the lowest leaves, and DI of the lowest leaves exceeded that of middle and upper leaves). These findings that highlight the importance of the topsoil water content in determining the rust intensity are supported by other rusts in some cultivated crops that use irrigation such as soybean, coffee (Coffea arabica), sugar cane cultivars (Saccharum spp.), and blackberry (Rubus laciniatus). These studies showed that irrigation is known to increase the topsoil water content and changes the microclimate within the plant canopy, including by increasing the duration of leaf wetness and by reducing canopy temperatures, thus increasing rust intensity (e.g., severity). Such effects were most pronounced for the lowest leaves, and resulted in higher rust intensity than in the upper leaves (de Paiva Custódio et al. 2014; Johnson and Mahaffee, 2010; Sikora et al. 2014; Taylor 1992). Another study found that, even though drip irrigation was applied to plants, the coffee rust (Hemileia vastatrix) intensity was not affected by the amount of irrigation, because the topsoil remained dry due to the burying of drip emitters at a depth of $0.25 \mathrm{~m}$ in the soil, within the root zone (Paiva et al. 2011). This suggests a potential management

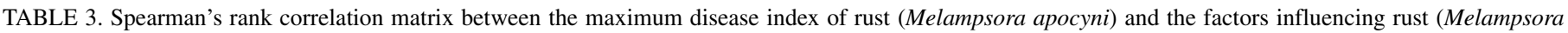
apocyni) intensity in cultivated and wild Apocynum venetum plants ${ }^{\mathrm{a}}$

\begin{tabular}{|c|c|c|c|c|c|c|c|}
\hline Plants, parameters & DI & Temp & Precip & Soil water & Coverage & Density & Ured \\
\hline \multicolumn{8}{|l|}{ Cultivated } \\
\hline Temp & 0.128 & $\ldots$ & $\ldots$ & $\ldots$ & $\ldots$ & $\ldots$ & $\ldots$ \\
\hline Precip & $0.461 *$ & 0.059 & $\ldots$ & $\ldots$ & $\ldots$ & $\ldots$ & $\ldots$ \\
\hline Soil water & $0.891 * *$ & -0.051 & 0.267 & $\ldots$ & $\ldots$ & $\ldots$ & $\ldots$ \\
\hline Coverage & $0.558 * *$ & 0.106 & -0.048 & $0.691 * *$ & $\ldots$ & $\ldots$ & $\ldots$ \\
\hline Density & $0.549 * *$ & 0.041 & -0.106 & $0.744 * *$ & $0.829 * *$ & $\ldots$ & $\ldots$ \\
\hline Ured & $0.716 * *$ & $-0.632 * *$ & $0.632 * *$ & $0.807 * *$ & $0.761 * *$ & $0.772 * *$ & $\ldots$ \\
\hline Diversity & 0.273 & $0.456^{*}$ & 0.198 & 0.195 & $0.427 * *$ & 0.083 & -0.097 \\
\hline \multicolumn{8}{|l|}{ Wild } \\
\hline Temp & -0.193 & $\ldots$ & $\ldots$ & $\ldots$ & $\ldots$ & $\ldots$ & $\ldots$ \\
\hline Precip & $0.805 * *$ & -0.102 & $\ldots$ & $\ldots$ & $\ldots$ & $\ldots$ & $\ldots$ \\
\hline Soil water & 0.152 & -0.208 & 0.163 & $\ldots$ & $\ldots$ & $\ldots$ & $\ldots$ \\
\hline Coverage & $0.445 * *$ & -0.083 & $0.401 *$ & $0.551 * *$ & $\ldots$ & $\ldots$ & $\ldots$ \\
\hline Density & $0.353 *$ & -0.121 & $0.457 * *$ & $0.426 * *$ & $0.878 * *$ & $\ldots$ & $\ldots$ \\
\hline Ured & $0.749 * *$ & -0.208 & $0.850 * *$ & -0.100 & 0.020 & 0.013 & $\ldots$ \\
\hline Diversity & $-0.367 *$ & 0.047 & $-0.341 *$ & -0.127 & $-0.487 * *$ & $-0.561 * *$ & 0.298 \\
\hline
\end{tabular}

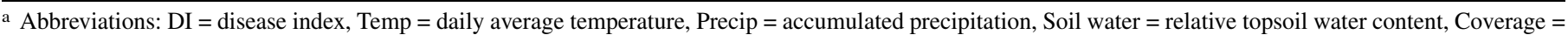
total vegetation coverage, Density $=A$. venetum density, Ured $=$ accumulated urediniospore concentration, and Diversity $=$ species diversity index. Asterisks $*$ and $* *=$ significance level at $P<0.05$ and 0.01 , respectively. 
strategy for improving rust management on cultivated $A$. venetum plants by reduction the topsoil water content through optimizing irrigation and possibly burying drip emitters underground. In wild plants, the topsoil water content did not significantly correlate with the rust intensity as a consequence of increased dry topsoil compared with cultivated plants during the period of rust development. As such, if considering reduction of rust in cultivated plants by optimizing irrigation, the relative water content of topsoil ( 0 - to 20 -cm depth) should decrease to below $65 \%$ or lower.

Studies on native grass species such as creeping bentgrass (Agrostis stolonifera) and small pasque flower (Pulsatilla pratensis) and on trees such as the willow (Salix spp.) have confirmed the role of increased total vegetation coverage (or canopy density) for reducing air movement and increasing leaf shading. These changes, in turn, lead to changes of the microclimate within the plant canopy. Such changes include an increase of leaf wetness duration and reduce the temperature and light intensity, conditions that are favorable for rust development (Liu et al. 2016; Toome et al. 2010; Wennström and Ericson 1991). This agrees with the findings of the current study, where total vegetation coverage in either wild or cultivated plants correlated positively with $\mathrm{DI}_{\max }$. However, the effect of total vegetation coverage on the microclimate was greater in wild plants than in cultivated plants. This effect seems to be caused by tall weeds in wild plants, including Phragmites communis, Achnatherum splendens, and Euphorbia spp. that always grow alongside Apocynum venetum plants. These plants form a tall mixed-plant community, unlike the mostly small-plant community in cultivated plants fields where species of the families

A

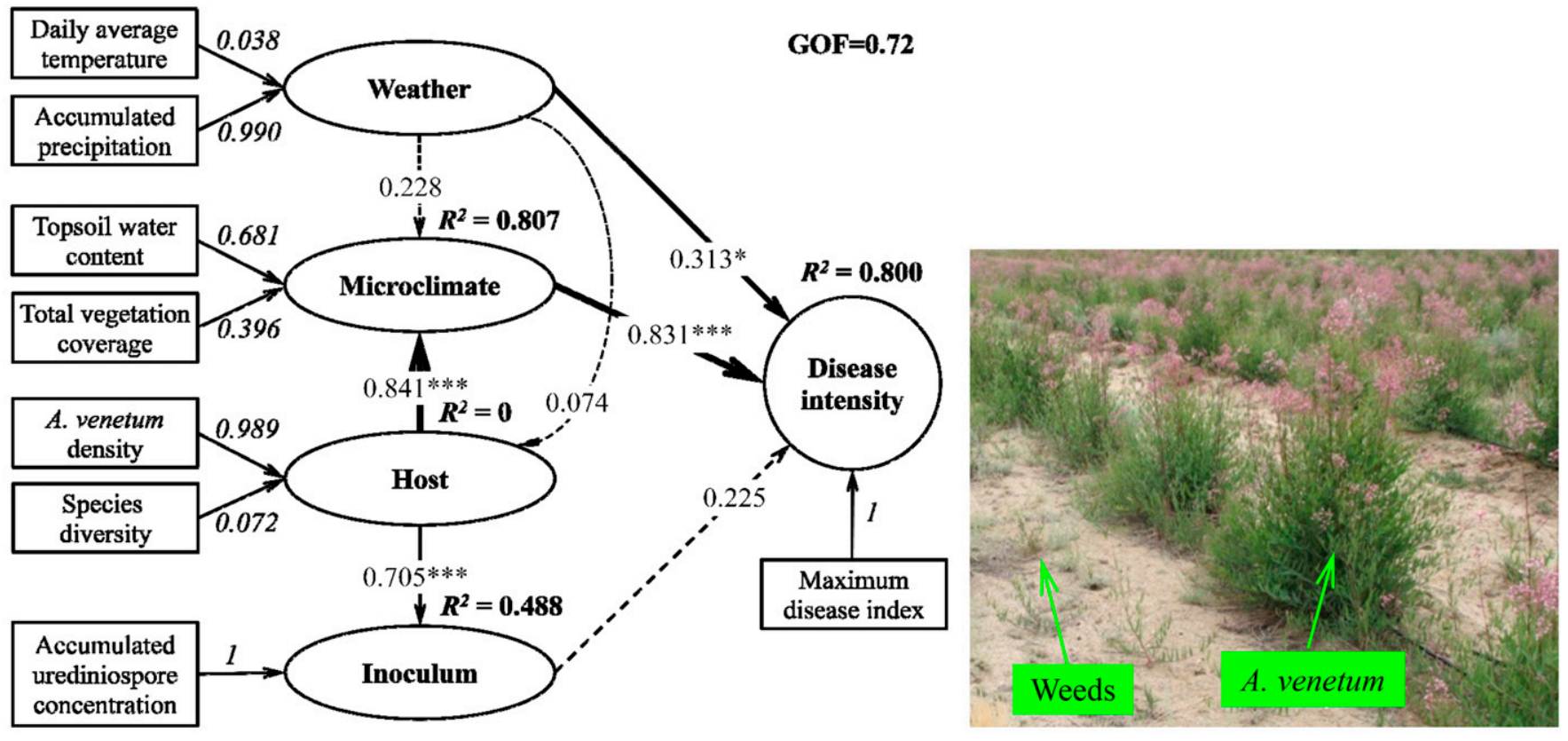

B

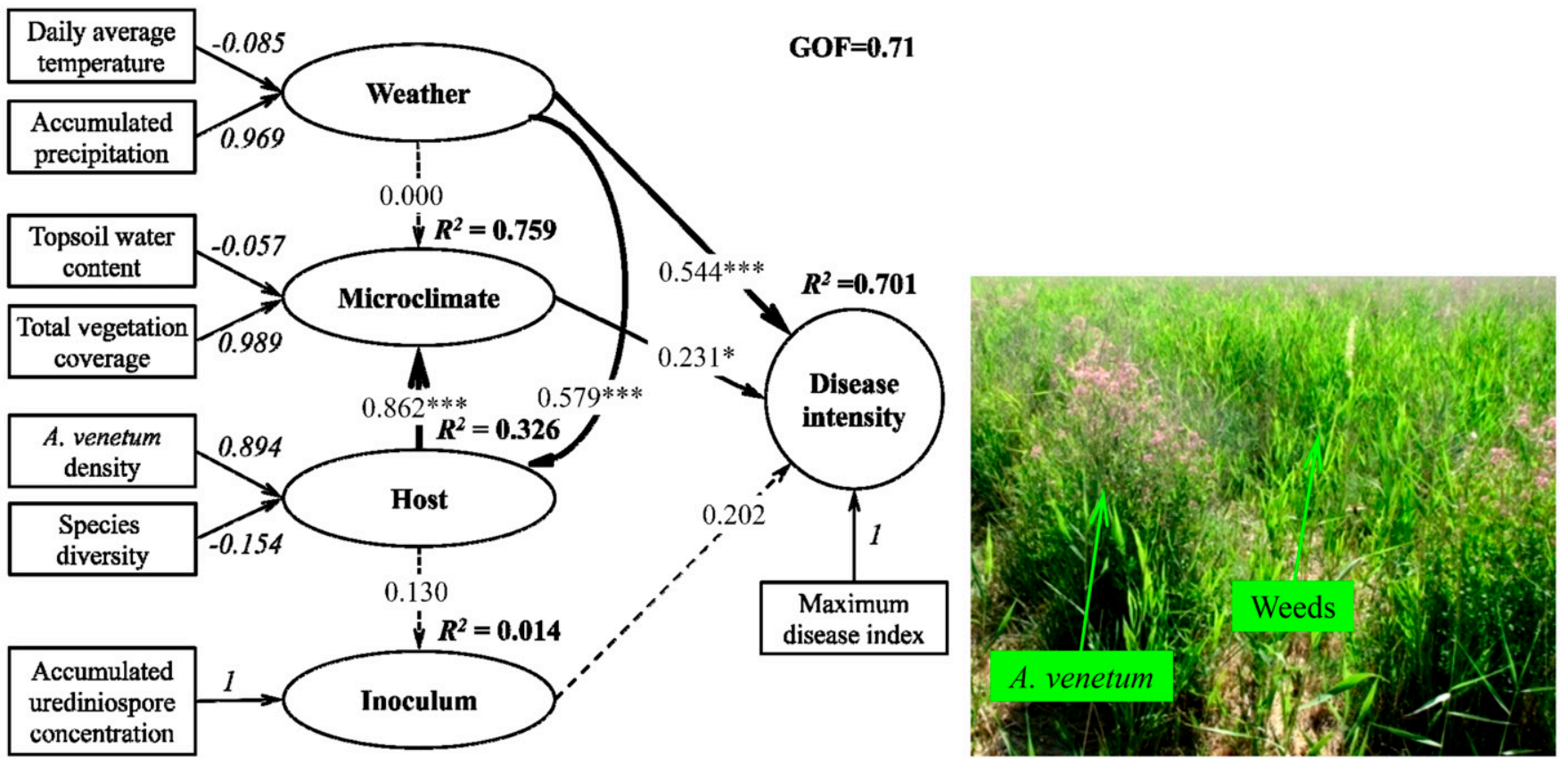

Fig. 6. Partial least squares path modeling (PLS-PM) to evaluate the effects of various factors on the disease intensity for A, cultivated and B, wild Apocynum venetum. Rectangles and ovals represent measured variables and latent variables, respectively. These are connected by arrows showing directed cause-and-effect relationships. Numbers above arrows are contribution coefficients of measurement variables to the latent variables. Numbers within arrows are standardized path coefficients. Pathways without significant effects $(P>0.05)$ are indicated by dashed arrows. $R^{2}$ values associated with response variables indicate the proportion of variation explainable by relationships with other variables. Asterisks *, **, and *** indicate significance levels at $P<0.05,0.01$, and 0.001 , respectively. 
Chenopodiaceae and Poaceae grew between rows and formed an independent plant community between the relatively large $A$. venetum plants. This lowers the density of the canopy of cultivated plants relative to that of the wild plants even under the same total vegetation coverage.

Increasing the host density in wheat (Triticum aestivum) cultivar mixtures (Chester 1946) and in a natural population of jewelweed (Impatiens capensis) (Lively et al. 1995) did not affect the rust intensity by changing the host-pathogen encounter rates when the total vegetation coverage of plant communities remained constant. In contrast, controlled-density studies in monocropping systems such as wheat indicated that rust intensity increased with density, and further indicated that the microclimatic conditions within the plant canopy were more conducive to rust infection because the total vegetation coverage of a single-plant system became higher with increasing plant density (Pfleeger and Mundt 1998). In the current study, the changes of $A$. venetum density in both cultivated and wild plants not only affected the microclimate via the total vegetation coverage but also affected the amount of captured M. apocyni urediniospores (inoculum), resulting in a corresponding variation of rust intensity. However, an abundance of taller weeds adjacent to $A$. venetum in wild plants reduced the host-pathogen encounter rates, leading to decreased inoculum with consequently reduced rust. Mitchell et al. (2002) also reported a negative correlation between rust severity (defined as percentage of leaf area infected by a single disease) and plant species diversity in grasslands for Puccinia spp. on Euphorbia corollata. In contrast, other studies have shown that species diversity has little influence on rust epidemics in situations where weather and other environmental conditions are conducive to the development of rust (Burdon et al. 2006). In the current study, the species diversity of Honggou was higher in 2013 than that of other years, yet DI ${ }_{\max }$ was also greater due to abundant rainfall. In addition, the lowheight weeds in cultivated plants had no significant effects on the amount of inoculum because they were a virtually independent plant community that provided little obstruction for the movement of M. apocyni urediniospores between the larger A. venetum plants. Accordingly, this explains why the extensive presence of diverse plants other than A. venetum, whether in cultivated or wild plants, did not always result in reduced rust intensity in the current study.

The concentration of $M$. apocyni urediniospores is in line with rust development in cultivated and wild plants. This indicates that the production of reinfecting inoculum mainly originated from local plants and had been produced continually on infected leaves. This ensures the potential for rust development in local plants as soon as the environmental conditions were conducive. In fact, with regard to rust, except for alloinfection (defined as infection in which the infector host is a different individual from the infected host individual), disease development is mainly caused by urediniospores spreading in air (Mundt 2009). High rates of autoinfection (defined as infection resulting from inoculum produced on the same host unit) contribute in a major way to rust development at small spatial scales (Mundt 2009). For example, autoinfection can cause more than $50 \%$ of the total stem rust infection in a perennial ryegrass (Lolium perenne) (Pfender 2006). However, autoinfection is often ignored in disease development because it is challenging to measure directly. In the current study, the effect of inoculum on $\mathrm{DI}_{\max }$ was insignificant in both cultivated and wild plants. This implies that the viewpoint that inoculum factor is only dominated by the concentration of $M$. apocyni urediniospores in the air may be incorrect. Still, the presence of sufficient quantities of urediniospores spreading through wind is an important factor for rust development. Although there was no direct evidence from historical studies that would indicate where the initial inoculum of rust had come from, the current study indicates that the production of the inoculum to initiate rust in either cultivated or wild plants most likely originated from local plants because no urediniospores were captured by air sampling until rust was observed. An understanding of the life cycle of M. apocyni, including how this pathogen overwinters when the stems die at the start of winter, would further contribute to a more comprehensive understanding of the rust development of A. venetum. Such knowledge may also indicate additional ways to reduce its damaging effects. Recently, Barua et al. (2018) investigated how some epidemics commence without the obvious presence of "alternate" or "green bridge" hosts for the stem rust pathogen Puccinia graminis f. sp. tritici, and found that urediniospores can survive in the absence of suitable host plants for up to a year and still germinate and successfully initiate infections of wheat seedlings. Hence, it is possible that similar survival capabilities apply for the rust cycle of $A$. venetum in China, and this would be worthwhile to investigate further.

In conclusion, we found considerable variations in rust intensity in both cultivated and wild plants across years, plant vertical direction, and sample sites, and clarified that precipitation plays a key role in the variation of year-to-year rust intensity. The topsoil water content and total vegetation coverage in cultivated and wild plants, respectively, were the critical determinants of rust intensity due to their effects on microclimate. For cultivated and wild plants, increasing A. venetum density not only increased the total vegetation coverage but also could increase the host-pathogen encounter rates, thus resulting in the rust becoming more severe. However, weeds in wild plants could alleviate A. venetum rust by reducing the host-pathogen encounter rates in years with less rain. We believe that this study provides novel information for $A$. venetum rust research. The presented results can be used to forecast and to control rust development in future.

TABLE 4. Indirect effects of various factors on the maximum disease index of rust (Melampsora apocyni) in the cultivated and wild Apocynum venetum plants ${ }^{\mathrm{a}}$

\begin{tabular}{|c|c|c|c|c|}
\hline \multirow[b]{2}{*}{ Pathway to $\mathrm{DI}^{\mathrm{b}}$} & \multirow[b]{2}{*}{ Effect } & \multirow[b]{2}{*}{ SE } & \multicolumn{2}{|c|}{$95 \% \mathrm{CI}$} \\
\hline & & & Lower & Upper \\
\hline \multicolumn{5}{|l|}{ Cultivated plants } \\
\hline Weather factor $\rightarrow$ Host factor $\rightarrow$ Inoculum factor $\rightarrow$ DI & -0.010 & 0.044 & -0.114 & 0.070 \\
\hline Host factor $\rightarrow$ Microclimatic factor $\rightarrow$ DI & 0.699 & 0.140 & 0.381 & 0.963 \\
\hline Host factor $\rightarrow$ Inoculum factor $\rightarrow$ DI & 0.115 & 0.123 & -0.122 & 0.366 \\
\hline Weather factor $\rightarrow$ Host factor $\rightarrow$ Microclimatic factor $\rightarrow$ DI & 0.119 & 0.069 & 0.016 & 0.268 \\
\hline Weather factor $\rightarrow$ Host factor $\rightarrow$ Inoculum factor $\rightarrow$ DI & 0.017 & 0.019 & -0.014 & 0.063 \\
\hline Host factor $\rightarrow$ Microclimatic factor $\rightarrow$ DI & 0.200 & 0.107 & 0.018 & 0.410 \\
\hline Host factor $\rightarrow$ Inoculum factor $\rightarrow$ DI & 0.027 & 0.029 & -0.024 & 0.091 \\
\hline
\end{tabular}

${ }^{a} \mathrm{CI}=$ confidence interval, Effect $=$ mean effect size, and $\mathrm{SE}=$ standard error.

b $\mathrm{DI}=$ disease intensity. 


\section{ACKNOWLEDGMENTS}

We thank the editor and anonymous reviewers for comments and suggestions that significantly improved this article.

\section{LITERATURE CITED}

Barua, P., You, M. P., Bayliss, K., Lanoiselet, V., and Barbetti, M. J. 2018. Extended survival of Puccinia graminis f. sp. tritici urediniospores: Implications for biosecurity and on-farm management. Plant Pathol. 67: 799-809.

Bletsos, F. A., Thanassoulopoulos, C. C., and Roupakias, D. G. 1999. Water stress and Verticillium wilt severity on eggplant (Solanum melongena L.). J. Phytopathol. 147:243-248.

Burdon, J. J., Thrall, P. H., and Ericson, L. 2006. The current and future dynamics of disease in plant communities. Annu. Rev. Phytopathol. 44: 19-39.

Chandrashekar, M., and Heather, W. A. 1981. The effect of pre-and postinoculation temperature on resistance in certain cultivars of poplar to races of Melampsora larici-populina Kleb. Euphytica 30:113-120.

Chester, K. S. 1946. The Nature and Prevention of Cereal Rusts as Exemplified in the Leaf Rust of Wheat, 2nd ed. Chronica Botanica, Waltham, MA.

Costes, E., Lauri, P. E., Simon, S., and Andrieu, B. 2013. Plant architecture, its diversity and manipulation in agronomic conditions, in relation with pest and pathogen attacks. Eur. J. Plant Pathol. 135:455-470.

Covarelli, L., Beccari, G., Tosi, L., Fabreb, B., and Frey, P. 2013. Three-year investigations on leaf rust of poplar cultivated for biomass production in Umbria, Central Italy. Biomass Bioenergy 49:315-322.

Cox, C. M., Garrett, K. A., Bowden, R. L., Fritz, A. K., Dendy, S. P., and Heer, W. F. 2004. Cultivar mixtures for the simultaneous management of multiple diseases: Tan spot and leaf rust of wheat. Phytopathology 94: 961-969.

Denchev, C. M. 1995. Bulgarian Uredinales. Mycotaxon 55:405-465.

de Paiva Custódio, A. A., Pozza, E. A., De Paiva Custódio, A. A., De Souza, P. E., Lima, L. A., and Da Silva, A. M. 2014. Effect of center-pivot irrigation in the rust and brown eye spot of coffee. Plant Dis. 98:943-947.

Efron, B., and Tibshirani, R. 1993. An Introduction to the Bootstrap. Chapman \& Hall Ltd., New York.

Eversmeyer, M. G., and Kramer, C. L. 2000. Epidemiology of wheat leaf and stem rust in the central great plains of the USA. Annu. Rev. Phytopathol. 38:491-513.

Gao, P., Liu, Q. T., Duan, T. Y., Meng, F. J., Huang, J. F., and Bai, Y. 2014. A method and special equipment are used to measure pathogenicity of Melampsora apocyni urediniospores. C. S. I. P. Office, Beijing, China (in Chinese).

Gao, P., Nan, Z. B., Wu, Y. N., Liu, Q. T., Meng, F. J., Huang, J. F., and Duan, T. Y. 2017. Identification of the pathogen causing rust disease of traditional Chinese herb Apocynum venetum. J. Plant Prot. 44:129-136 (in Chinese).

Gao, P., Nan, Z. B., Wu, Y. N., Liu, Q. T., Meng, F. J., Xiao, Z. C., and Duan, T. Y. 2015. Characteristics of photosynthetic physiological and growth with 8 Luobuma ecotypes in the Apocynum sp. and Poacynum sp. from Altay of Xinjiang, China. Acta Bot. Boreal. Occident. Sin. 35:2069-2077 (in Chinese).

Goodall, D. W. 1952. Some consideration in the use of point quadrats for the analysis of vegetation. Aust. J. Sci. Res. Ser. B Biol. Sci. 5:1-41.

Guo, Z. Q., Cao, Z. M., and Yu, Z. D. 2010. Germination conditions of urediniospores of Melampsora larici-populina. J. Northwest For. Univ. 25: 118-121 (in Chinese).

Habiken, G., and Zhao, J. B. 2011. Analysis on climate change in recent 50 years in Altay Prefecture, Xinjiang. Arid Zone Res. 28:83-89 (in Chinese).

Harveson, R. M., and Rush, C. M. 2002. The influence of irrigation frequency and cultivar blends on the severity of multiple root diseases in sugar beets. Plant Dis. 86:901-908.

Hiratsuka, N. 1937. Miscellaneous notes on the East Atlantic Uredinales with special reference to the Japanese species. J. Jap. Bot. 13:244-251.

Hu, R. L., and Qian, X. S. 1985. The adaptability research of A. venetum in the introduction experiment in Shaanxi province, China. Chin. Wild Plant Res. 2:7-12 (in Chinese).

Huber, L., and Gillespie, T. J. 1992. Modeling leaf wetness in relation to plant disease epidemiology. Annu. Rev. Phytopathol. 30:553-577.

Johnson, K. B., and Mahaffee, W. F. 2010. Factors influencing epidemiology and management of blackberry rust in cultivated Rubus laciniatus. Plant Dis. 94:581-588.

Kirbağ, S. 2004. New records of microfungi from Turkey. Pak. J. Bot. 36: 445-448.

Kou, Y. P., Li, J. B., Wang, Y. S., Li, C. N., Tu, B., Yao, M. J., and Li, X. Z. 2017. Scale-dependent key drivers controlling methane oxidation potential in Chinese grassland soils. Soil Biol. Biochem. 111:104-114.
Kriss, A. B., Paul, P. A., and Madden, L. V. 2010. Relationship between yearly fluctuations in Fusarium head blight intensity and environmental variables: A window-pane analysis. Phytopathology 100:784-797.

Lawrence, G. J., Dodds, P. N., and Ellis, J. G. 2007. Rust of flax and linseed caused by Melampsora lini. Mol. Plant Pathol. 8:349-364.

Li, Q., Gu, S. C., Wang, Y. L., Li, Z. J., Li, Z. L., and Li, J. Q. 2013. Morphology of urediniospores and infecting structure of Melampsora pruinosae in Populus euphratica and P. pruinosa. Acta Phytopathol. Sin. 43:267-273 (in Chinese).

Liu, Y., Zhang, Y. W., Nan, Z. B., and Duan, T. Y. 2016. Progress of research into the effects of native grassland management practices on plant disease. Acta Ecol. Sin. 36:4211-4220 (in Chinese).

Lively, C. M., Johnson, S. G., Delph, L. F., and Clay, K. 1995. Thinning reduces the effect of rust infection on jewelweed (Impatiens capensis). Ecology 76:1859-1862.

Lundquist, J. E. 2007. The relative influence of diseases and other smallscale disturbances on fuel loading in the Black Hills. Plant Dis. 91: 147-152.

Ma, Z., Morgan, D. P., and Michailides, T. J. 2001. Effects of water stress on Botryosphaeria blight of pistachio caused by Botryosphaeria dothidea. Plant Dis. 85:745-749.

McCracken, A. R., Dawson, W. M., Watson, S., and Allen, C. Y. 2000. Pathotype composition in Melampsora epitea populations occurring on willow (Salix) grown in mixed and monoculture plantations. Eur. J. Plant Pathol. 106:879-886.

Mitchell, C. E., Tilman, D., and Groth, J. V. 2002. Effects of grassland plant species diversity, abundance, and composition on foliar fungal disease. Ecology 83:1713-1726.

Mundt, C. C. 2009. Importance of autoinfection to the epidemiology of polycyclic foliar disease. Phytopathology 99:1116-1120.

Nevodovskii, G. S. 1956. Pages 227-229 in: Cryptogamic Flora of Kazakhstan, Vol. 1. Kazakhstan Academy of Sciences, Alma-Ata, Kazakhstan.

Norman, J. M. 1982. Simulation of microclimates. Pages 65-99 in: Biometeorology in Integrated Pest Management. J. L. Hatfield and I. J. Thomason, eds. Academic Press, Inc., New York.

Paiva, B. R. T. L., Souza, P. E., Scalco, M. S., and Santos, L. A. 2011. Progress of rust in coffee plants in various densities of cultivation in irrigated planting after pruning. Sci. Agrotechnol. 35:137-143 (in Portuguese).

Peng, X. M., Zhang, W. M., Wang, Y. Y., Gu, G. P., and Lu, C. M. 2008. Genetic diversity study on wild population of Apocynum venetum using RAPD marker. J. Nanjing Norm. Univ Nat. Sci. Ed. 31:92-96 (in Chinese).

Pfender, W. F. 2006. Interaction of fungicide physical modes of action and plant phenology in control of stem rust of perennial ryegrass grown for seed. Plant Dis. 90:1225-1232.

Pfleeger, T. G., and Mundt, C. C. 1998. Wheat leaf rust severity as affected by plant density and species proportion in simple communities of wheat and wild oats. Phytopathology 88:708-714.

Ping, X. Y., Lin, C. C., Bai, Y., Liu, Q. T., and Lu, X. S. 2014. The ecological effects of planting Apocynum venetum in the plain desert of the Altay Region, Xinjiang Province. Acta Pratac. Sin. 23:49-58 (in Chinese).

Saccardo, P. A. 1895. Melampsora. Sylloge Fungorum 11:183.

Sanchez, G. 2013. PLS Path Modeling with R. Trowchez Editions, Berkeley, CA.

Schmitz, H. F., and Grant, R. H. 2009. Precipitation and dew in a soybean canopy: Spatial variations in leaf wetness and implications for Phakopsora pachyrhizi infection. Agric. For. Meteorol. 149:1621-1627.

Sikora, E. J., Allen, T. W., Wise, K. A., Bergstrom, G., Bradley, C. A., Bond, J., Brown-Rytlewski, D., Chilvers, M., Damicone, J., and DeWolf, E. 2014. A coordinated effort to manage soybean rust in North America: A success story in soybean disease monitoring. Plant Dis. 98:864-875.

Song, R. J., and Zhou, J. 2015. Microemulsion liquid chromatographic method for simultaneous separation and determination of six flavonoids of Apocynum venetum leaf extract. J. Chromatogr. B 995-996:8-14.

Tai, F. L. 1979. Page 534 in: Sylloge Fungorum Sinicorum. Science Press, Beijing (in Chinese).

Taylor, P. W. J. 1992. Evidence for the existence of a single race of common rust caused by Puccinia melanocephala, in Australian sugar cane cultivars. Aust. J. Agric. Res. 43:443-450.

Thevs, N., Zerbe, S., Kyosev, Y., Rozi, A., Tang, B., Abdusalih, N., and Novitskiy, Z. 2012. Apocynum venetum L. and Apocynum pictum Schrenk (Apocynaceae) as multi-functional and multi-service plant species in Central Asia: A review on biology, ecology, and utilization. J. Appl. Bot. Food Qual. 85:159-167.

Toome, M., Heinsoo, K., Holm, B., and Luik, A. 2010. The influence of canopy density on willow leaf rust (Melampsora epitea) severity in willow short rotation coppice. Biomass Bioenergy 34:1201-1206.

Tranzschel, W. A. 1891. New kinds fungi of Melampsora sp. Pages 137-140 in: Botanical Notes issued upon the Botanical Garden of the Imperial St. Petersburg University, 3. 
Turechek, W. W. 2004. Nonparametric tests in plant disease epidemiology: Characterizing disease associations. Phytopathology 94:1018-1021.

van Bruggen, A. H. C., and Finckh, M. R. 2016. Plant diseases and management approaches in organic farming systems. Annu. Rev. Phytopathol. 54:25-54.

Vialle, A., Frey, P., Hambleton, S., Bernier, L., and Hamelin, R. C. 2011. Poplar rust systematics and refinement of Melampsora species delineation. Fungal Divers. 50:227-248.

Waggoner, P. E. 1965. Microclimate and plant disease. Annu. Rev. Phytopathol. 3:103-126.

Wennström, A., and Ericson, L. 1991. Variation in disease incidence in grazed and ungrazed sites for the system Pulsatilla pratensis-Puccinia pulsatillae. Oikos 60:35-39.

Widin, K. D., and Schipper, A. L., Jr. 1980. Epidemiology of Melampsora medusae leaf rust of poplars in the north central United States. Can. J. For. Res. 10:257-263.
Xu, B., Zhao, Z. Y., and Zhuang, J. Y. 2013. Rust fungi hitherto known from Xinjiang (Sinkiang), northwestern China. Mycosystema 32:170-189.

Yang, H. J., Wu, M. Y., Liu, W. X., Zhang, Z., Zhang, N. L., and Wan, S. Q. 2011. Community structure and composition in response to climate change in a temperate steppe. Glob. Change Biol. 17:452-465.

Zadoks, J. C., and Schein, R. D. 1979. Epidemiology and Plant Disease Management. Oxford University Press, New York.

Zeng, S. M., and Luo, Y. 2006. Long-distance spread and interregional epidemics of wheat stripe rust in China. Plant Dis. 90:980-988.

Zhang, Y. P., Guo, J. B., and Ma, Z. H. 2007. Correlation analysis of multitemporal canopy reflectance and disease index of wheat stripe rust. J. Plant Prot. 34:507-510 (in Chinese).

Zhuang, J. Y. 1989. Rust fungi from the desert of northern Xinjiang. Mycosystema 8:259-269 (in Chinese). 